\title{
MANAJEMEN PENGEMBANGAN KURIKULUM PESANTREN DI JAWA TIMUR
}

\author{
Riayatul Husnan \\ UIN Kiai Haji Achmad Siddiq Jember \\ husnansitubondo@gmail.com \\ Muhlas \\ SMA Nurul Ulum Umbulsari Jember \\ nurmuhlasnu@gmail.com
}

DOI: 10.35719/jieman.v3i2.71

\begin{abstract}
Abstrak
Kurikulum pondok pesantren merupakan hal yang sangat urgen dalam mencapai sebuah keberhasilan pembelajaran. Padahal yang kita ketahui pondok pesantren tidak memiliki kurikulum secara resmi dari pemerintah, karena hal itu merupakan kebijakan dari masing-masing pengasuh pondok pesantren. Kajian ini difokuskan untuk mengungkap kosep perencanaan, pola pelaksanaan, model evaluasi manajemen pengembagan kurikulum pesantren di Jawa Timur. Pendekatan yang digunakan dalam penelitian ini pendekatan diskriptif kualitatif dengan penerapan studi kasus. Teknik pengumpulan datanya menggunakan observasi, wawancara, dokumenter, sedangkan analisis datanya menggunakan reduksi data, penyajian data, verifikasi dan kesimpulan. Hasil penelitian menunjukkan bahwa pola perencanaan manajemen pengembagan kurikulum pesantren menghasilkan program kegiatan, pertama, penyusunan program kerja visi misi dan tujuan. Kedua, adanya keterlibatan para ustadz dan stakeholders. Pola pelaksanaan manajemen pengembangan kurikulum pesantren diesuaikan degan visi-misi pesantren melalui kegiatan, $5 \mathrm{~S}$ antara lain: strategi inquiry, strategi inquiry sosial, strategi exposition learning, strategi rote learning, strategi contextual teaching learning. Model evaluasi manajemen
\end{abstract}


JIEMAN: Journal of Islamic Educational Management

pengembangan kurikulum pesantren meliputi evaluator, ruang lingkup atau objek evaluasi, alat evaluasi, kebijakan evaluasi.

Kata Kunci: manajemen pengembangan kurikulum, pondok pesantren

\begin{abstract}
The Islamic boarding school curriculum is very urgent in achieving a learning success. In fact, what we know is that Islamic boarding schools do not have an official curriculum from the government, because it is the policy of each boarding school caregiver. This study is focused on revealing: planning concepts, Implementation patterns, evaluation models of islamic boarding school curriculum development management in East Java. The approach used in this study is a qualitative descriptive approach with the application of case studies. Data collection techniques use observation, interview, documentary. While the data analysis uses data reduction, data display, verification, and conclucation. the results of the study show that the pattern of management planning for the development of the Islamic boarding school curriculum produces a program of activities, first, the preparation of the work program of the vision, mission and objectives. Second, the involvement of the asatidz board and stakeholders. The implementation pattern of Islamic boarding school curriculum development management is adjusted to the vision and mission of the pesantren through activities, $5 \mathrm{~S}$, including: inquiry strategy, social inquiry strategy, exposition learning strategy, rote learning strategy, contextual teaching learning strategy evaluation model of curriculum development management includes evaluator, scope or object of evaluation, evaluation tool, evaluation policy.
\end{abstract}

Keywords: management of curriculum development, Islamic boarding school

\title{
Pendahuluan
}

Manajemen kurikulum salah satu aspek yang berpengaruh terhadap keberhasilan pembelajaran dalam lembaga pendidikan. di samping itu, kurikulum merupakan suatu sistem program pembelajaran untuk mencapai tujuan institusional pada lembaga pendidikan, sehingga kurikulum memegang peranan penting dalam mewujudkan sekolah yang bermutu atau berkualitas. Untuk menun- 
jang keberhasilan kurikulum, diperlukan upaya pemberdayaan bidang manajemen atau pengelolaan kurikulum. ${ }^{1}$

Kurikulum disusun sesuai dengan jenjang pendidikan dalam kerangka Negara Kesatuan Republik Indonesia dengan memperhatikan: a) peningkatan iman dan takwa, b) peningkatan akhlak mulia, c) peningkatan potensi, kecerdasan, dan minat peserta didik, d) keragaman potensi daerah dan lingkungan, e) tuntutan pembangunan daerah dan nasional, f) tuntutan dunia kerja, g) tuntutan pengembangan ilmu pengetahuan, teknologi, dan seni, h) agama, i) dinamika perkembangan global, dan j) persatuan nasional dan nilai-nilai kebangsaan. ${ }^{2}$

Salah satu lembaga pendidikan tertua di Indonesia adalah pesantren. Pesantren jika disandingkan dengan lembaga pendidikan yang pernah muncul di Indonesia merupakan sistem pendidikan tertua saat ini yang dianggap sebagai produk budaya Indonesia yang indigenious. Pendidikan ini semula merupakan pendidikan agama Islam yang dimulai sejak munculnya masyarakat Islam di nusantara pada abad ke-13. Beberapa abad kemudian penyelenggaraan pendidikan. Ini semakin teratur dengan munculnya tempat-tempat pengajian (enggon ngaji). ${ }^{3}$

Keberhasilan sistem pendidikan dalam suatu pondok pesantren tidak terlepas dari manajemen kurikulum yang dipergunakan. Sistem manajemen kurikulum sangat berperan aktif dalam kemajuan dan keberhasilan perkembangan sebuah pondok pesantren, oleh karenanya manajemen sangat di butuhkan untuk terwujudnya pondok pesantren yang terkoordinir dan dalam

1 Hasan Sodiqin dan Didin Nurdin. "Kemampuan Manajerial Kepala Madrasah dan Kinerja Mengajar Guru dalam Mutu Pendidikan”, Jurnal Administrasi Pendidikan.Vol. XXIII. (2006) No. 2

${ }^{2}$ Undang-Undang Republik Indonesia No. 20 Tahun 2003 Tentang Sistem Pendidikan Nasional.

${ }^{3}$ Abdullah Idi, Pengembangan Kurikulum Teori E Praktik, (Yogyakarta: ArRuzz Media 2016), 176. 
pelaksanaanya dapat berjalan dengan efektif dan efisien hingga tercapailah tujuan pondok pesantren yang di inginkan. ${ }^{4}$

Manajemen kurikulum pesantren tidak hanya melibatkan pihak pesantren akan tetapi juga melibatkan pihak luar pesantren yaitu masyarakat secara umum dalam perencanaan. Dalam manajemen kurikulum pesantren terdapat program majlis dzikir yang tidak hanya diikuti oleh santri tetapi masyarakat secara umum. Disamping materi-materi pelajaran kitab kuning yang dipelajari dengan sistem pembelajaran aktif, Program majlis dzikir juga menjadi ikon pesantren salah satunya di kabupaten Jember dan begitupun kebupaten lainnya dengan tujuan agar lebih dikenal oleh masyarakat secara umum. Pada kenyataanya ditemukan banyak sekali pesantren yang belum berpikir kearah bagaiamana mendesain kurikulumnya unggul dengan capaian output dan outcome-nya yang berkualitas, khususnya pada pesantren salaf atau tradisional, kurikulum yang digunakan adalah mengikuti apa yang ada di dalam kitab-kitab kuningsaja, mengalir sesuai apa yang disampaikan oleh kiai atau pengasuhnya. Kegiatankegiatan pendukkung untuk menuju kehidupan masa yang akan datang bagi santribelum banyak diberikan. ${ }^{5}$

Kurikulum pesantren di Jawa Timur saat ini sebagaimana kurikulum lembaga pesantren di wilayah-wilayah yang lain yakni terbagi menjadi kurikulum pendidikan formal dan non formal. Pendidikan formal pesantren meliputi pendidikan Madrasah Tsanawiyah dan madrasah diniyah yang diselenggarakan secara klasikal. Sedangkan pendidikan non formal yaitu pengajian kitab kuning, pembelajaran Al-Qur'an dan kitab-kitab keislaman lainnya yang langsung dipimpin oleh pengasuh dan asatidz dan asatidzah di pondok pesantren. Selain kajian kitab-kita tersebut

${ }^{4}$ Euis Kokom, Yaya Suryana. Manajemen Kurikulum Pesantren, Jurnal $\begin{array}{llllll}\text { Islamic Education } & \text { Manajemen } & 2 & \text { (1) } & \text { (2017): } & 39-48\end{array}$ https://journal.uinsgd.ac.id/index.php/isema/article/view/4995

${ }^{5}$ Sunaryo Putro, Pengembangan KurikulumPondok Pesantren Modern $\begin{array}{llllllll}\text { Ad-dhuha. Jurnal: Tarbawi, Vol } 17 & \text { No } & 1 & \text { (2020): } & 86-97\end{array}$ https://ejournal.unisnu.ac.id/JPIT/article/download/1109/pdf 
juga terdapat kursus bahasa inggris, ketrampilan pidato dan kursus bahasa Arab yang aktif diselenggarakan setiap malam selasa dan jumat secara bergantian.

Manajemen kurikulum Pesantren di Jawa Timur contohnya di Kabupaten Jember juga memiliki kurikulum yang tidak tertulis dalam menumbuh kembangkan nilai-nilai islam yang berperan penting dalam membentuk karakter santri yang hidup di pesantren. nilai-nilai tersebut menjadi landasan dan motor penggerak seluruh aktivitas yang ada di pesantren. Nilai-nilai tersebut terdiri dari: (a) keikhlasan, (b) kesederhanaan, (c) kemandirian, (d) persaudaraan, dan (e) kebebasan dalam menentukan perjuangan untuk kehidupan yang disiplin.

\section{Pembahasan}

\section{Konsep Perencanaan Manajemen Pengembangan Kurikulum Pesantren diJawa Timur}

Konsep perencanaan manajemen pengembangan kurikulum Pesantren yang dilakukan pertama merencanakan kurikulum, karna merupakan fungsi utama yang fundamental dalam sebuah manajemen dan juga sebagai lembaga pendidikan yang bernafaskan keislaman pesantren, tentunya harus memiliki konsep perencanaan kurikulum yang jelas agar apa yang menjadi target lembaga dapat tercapai secara maksimal.

Perencanaan dalam pendidikan merupakan sebagai fungsi manajemen pendidikan. Fungsi perencanaan tersebut untuk menentukan keadaan yang sebaik-baiknya dari hubungan-hubungan sumber daya internal dan eksternal dalam suatu sistem pendidikan dengan keadaaan yang dinamis serta cara yang efisien dan efektif untuk mencapai tujuan yang diinginkan. ${ }^{6}$

Penerapan kurikulum di pondok pesantren dimulai dari tahap perencanaan. Pada tahap perencanaan seluruh pihak yang terkait mulai dari stakeholder, ustadz-ustadzah melakukan musyawaroh dalam menetapkan kurikulum. Kurikulum yang dimusyawarohkan

\footnotetext{
${ }^{6}$ Nida Uliatunida, "Perencanaan Kurikulum untuk Mencapai Tujuan
} Pendidikan” Jurnal Ilmu Pendidikan dan Dakwah, Vol.2 No 1. (2020), 46. 
semua yang terkait struktur kurikulum, pengajaran dan waktu. ${ }^{7}$ Untuk mencapai tujuan kurikulum diperlukan peran serta para Stakeholder dalam bergerak yang didasarkan pada visi dan misi Pesantren . Dengan hal ini kegiatan yang telah direncanakan antara lain: kegiatan sholat berjamaah, bacaan Manaqib, Ngaji al-qur'an, kajian kitab kuning, diskusi dan bahsul masail dan Kegiatankegiatan lainnya yang tujuannya untuk menunjang dalam proses pembentukan karakter santri.

Penyusunan program kerja, seiring dengan prinsip dinamitas zaman serta fleksibilitas kebutuhan masyarakat, maka pesantren mesti secara kontinyu melakukan perubahan demi perubahan menuju perbaikan (dinamisasi). Perubahan ini mempunyai tujuan yang sifatnya penyesuaian diri dengan lingkungan agar tujuan pesantren sesuai dengan kebutuhan atau tuntutan masyarakat masa kini.

Pengasuh atau kiai pesantren dalam melakukan pengelolaan ini mengacu pada peraturan Pemerintah Republik Indonesia Nomor 55 tahun 2007 tentang Pendidikan Agama dan Keagamaan. Pasal 5 ayat 1 yang berbunyi "Kurikulum pendidikan agama dilaksanakan sesuai Standar Nasional Pendidikan. Dan ayat 8 "Satuan pendidikan dapat menambah muatan pendidikan agama sesuai kebutuhan." 8 Pada hakikatnya pengurus mengadakan agenda untuk melakukan penyusun program setiap awal tahun, pengurus melakukan rapat dengan para guru dan dewan asatidz untuk membahas langkahlangkah apa saja yang akan dilakukan ke depan agar pondok pesantren dapat diminati oleh masyarakat. Perlu disadari oleh semua pihak bahwa minat masyarakat terhadap pesantren saat ini mulai merosot. Oleh sebab itu, selaku pendidik yang ada di kalangan pesantren harus membuat terobosan yang kiranya dapat menarik

${ }^{7}$ Nurul Indana, Leny Nurvita, "Implementasi Manajemne Kurikulum Pesantren,” Al-Idaroh: Jurnal Study Manajemen Pendidikan Islam, V.4 No 1. (2020): 30-51

https://jurnal.stituwjombang.ac.id/index.php/alidaroh/article/download/129/87/310

${ }^{8}$ Peraturan Pemerintah Republik Indonesia Nomor 55 Tahun 2007

Tentang Pendidikan Agama dPendidikan Keagamaan 
minat masyarkat agar puta putrinya dimondokkan dan sekolah di pesantren ini.

Pengurus pesantren pada hakekatnya terdiri dari struktur tenaga pendidik dan kependidikan, di mana setiap tenaga pendidik dan kependidikan memiliki spesifikasi tugas-tugas yang menuntut kompetensi pelakunya, dukungan fasilitas yang tepat dan memadai, dan kondisi yang kondusif bagi terlaksananya tugas-tugas tenaga pendidik dan kependidikanan itu. Spesifikasi tugas-tugas Pesantren menggambarkan spesifikasi kemampuan tenaga pendidik dan kependidikan yang mendukung pelaksanaan tugas/tenaga pendidik dan kependidikan itu. Analisis seperti ini disebut analisis tenaga pendidik dan kependidikan (job analysis). ${ }^{9}$

Untuk mengelola sumber daya pendidikan yang terlibat didalamnya, dibutuhkan seorang pemimpin yang bertanggung jawab untuk membantu ketercapaian tujuan. Keberadaan kepala Pesantren didalam lembaga pendidikan sangat penting, karena ia adalah penentu kebijakan yang diambil dan pengendali jalannya kegiatan pendidikan. ${ }^{1}$ Selain itu, dalam hal mengembang ${ }^{0}$ kan kompetensi kemampuan tenaga pendidik dan kependidikan, kepala madrasah memberikan pelatihan kepada sumber daya manusia yang ada dilembaga pendidikan tersebut. Pengembangan lembaga atau organizational development, menurut Megginson $\mathrm{dkk}$ dalam Baharuddin mengatakan, pengembangan adalah proses jangka panjang untuk menumbuhkan potensi- potensi yang dimiliki organisasi dan meningkatkan efektifitas kinerja. ${ }^{1}$ Hal yang sama juga diungkap oleh Schein pengembangan lembaga adalah kegiatan seluruh staf pimpinan (manajer), karyawan dan lain-lain yang diarahkan menuju pembuatan dan penjagaan kesehatan lembaga sebagai suatu sistem lokal. Dalam konteks ini, keterlibatan guru

${ }^{9}$ Surya Dharma, Direktorat Jenderal Peningkatan Mutu Pendidik Dan

Tenaga Kependidikan (Jakarta: Direktur Tenaga Kependidikan, 20o8), 6

1 Bambang Ismaya, Pengelolaan pendidikan (Bafdung: PT Rafika Aditama, 2015),115

1 Baharuddin, Pengembangan Pendidikan Isl'am Menuju Pengelolaan yang Professional dan Kompetitif, (Malang: UIN Maliki Press, 2012), 99 
dalam setiap aktivitas pekerjaan yang berkaitan dengan sekolah perlu dibudidayakan, agar tercipta iklim organisasi yang sehat, seperti halnya yang dilakukan oleh pesantren yang ada di kabupaten Jember, kepala madrasah memberikan kesempatan kepada guru untuk terlibat aktif dalam setiap event yang di adakan oleh madrasah. Keterlibatan guru menjadi sangat penting, mengingat guru merupakan tenaga pendidik yang terlibat dan bersinggungan langsung dengan siswa.

Selain itu, dalam hal mengembangkan kompetensi kemampuan tenaga pendidik dan kependidikan, pimpinan Pondok pesantren memberikan pelatihan kepada sumber daya manusia yang ada dilembaga pendidikan tersebut. Pengembangan lembaga atau organizational development, menurut Megginson $\mathrm{dkk}$ dalam Baharuddin mengatakan, pengembangan adalah proses jangka panjang untuk menumbuhkan potensi- potensi yang dimiliki organisasi dan meningkatkan efektifitas kinerja. ${ }^{1}$

\section{Pola Pelaksanaan Manajemen Pengembangan Kurikulum Pesantren di Jawa Timur}

Pelaksanaan manajemen kurikulum merupakan bagian yang integral dari keseluruhan manajemen yang diterapkan di semua jenis dan jenjang pendidikan. Bahkan tidak berlebihan jika dikatakan bahwa keberhasilan suatulembaga pendidikan sangat ditentukan oleh manajemen kurikulumnya. Istilah manajemen dan administrasi pendidikan yang dipergunakan dalam penulisan ini mengandung arti yangsamayaitupengelolaan pendidikan. ${ }^{1}$

Berdasarkan pola pelaksanaan kurikulum yang akan diterapkan dalam pesantren dimulai dari penempatan santri wajib mukim di pesantren. Kemudian seluruh santri wajib mengikuti peraturan pesantren dan juga seluruh santri wajib mengikuti

1 Baharuddin, Pengembangan Pendidikan Islªm Menuju Pengelolaan yang Professional dan Kompetitif, (Malang: UIN Maliki Press, 2012), 99

1 Amri Yusuf Lubis, "Pelaksanaan Manajeme ${ }^{3} n$ Kurikulum pada SMA Negeri 1 Buenggala Kabupaten Aceh Besar.” Jurnal, Administrasi Pendidikan Pascasarjana Universitas Syiah Kuala. Vol.3 No.1 2015), 14 
kegiatan pondok yang telah disosialisasikan oleh pengurus dan para asatidz seperti shalat berjama'ah, kajian kitab kuning, khitobah, ngaji al-Qur'an dll. Dan juga ada kegiatan Madrasah Diniyah dan Madrasah Tsanawiyah yang terdapat pengelompokan kitab kuning sesuai dengan kelasnya.

Strategi dan metode pelaksanaan kurikulum yang digunakan di salah satu pondok pesantren di Jawa Timur, khususnya di Kabupaten Jember, yaitu berusaha memadukan dan menempatkan dengan seimbang antara mendengarkan, melihat, berfikir, dan praktek atau beramal, sehingga memperoleh pemahaman secara terpadu. Hal ini sesuai dengan apa yang dikatakan salah satu pengasuh Pondok Pesantren di Jember, Beliau mengatakan bahwa ada beberapa strategi yang sudah di terapkan di lembaga pondok pesantren antara lain:

1. Strategi inquiry, meliputi: metode diskusi, tanya jawab, pemberian tugas, bahts al-masail, dan jigsaw.

2. Strategi inquiry sosial, meliputi: metode karya wisata dan percobaan (eksperimen)

3. Strategi exposition learning, meliputi: metode wetonan atau bandongan dan ceramah

4. Strategi rote learning, meliputi metode hafalan

5. Strategi contextual teaching learning, meliputi: demonstrasi dan praktik.

Proses pelaksanaan kurikulum di pesantren menggunakan beberapa metode diantaranya, adalah: metode diskusi, ceramah, tanya jawab, bahsul masail, wetonan atau hafalan, tergantung mata pelajaran dan materi yang disampaikan pada santri, karena masingmasing mata pelajaran menggunakan metode yang berbeda sesuai dengan keinginan masing-masing tenaga pengajar.

Pola pelaksanaan kurikulum adalah petunjuk dan cara bagaimana kurikulum itu bisa dilaksanakan di Pesantren . Berkaitan dengan Strategi dan metode pelaksanaan manajemen kurikulum yang digunakan di Pesantren, Sebagaimana yang disampaiakan salah satu pengasuh pondok pesantren di Jember Jawa Timur. Beliau mengatakan, "Proses pelaksanaan kurikulum di Pesantren ini 
menggunakan beberapa metode di antaranya, adalah: metode diskusi, ceramah, tanya jawab, bahsul masail, wetonan atau hafalan, tergantung mata pelajaran dan materi yang disampaikan pada santri, karena masing-masing mata pelajaran menggunakan metode yang berbeda sesuai dengan keinginan masing-masing tenaga pengajar." Pendapat di atas sesuai dengan Peraturan Pemerintah RI Nomor 19 Tahun 2005 tentang Standar Nasional Pendidikan pada Bab IV tentang Standar Proses, yaitu pada Pasal 19 ayat 1 dan 2, sebagaimana di bawah ini:

1. Proses pembelajaran pada satuan pendidikan diselenggarakan secara interaktif, inspiratif, menyenangkan, menantang, memotivasi peserta didik untuk berpartisipasi aktif, serta memberikan ruang yang cukup bagi prakarsa, kreativitas, dan kemandirian sesuai dengan bakat, minat, dan perkembangan fisik serta psikologis peserta didik.

2. Dalam proses pembelajaran pendidik memberikan keteladanan.

Peraturan pemerintah di atas, menjelaskan tidak adanya peraturan jenis-jenis strategi dan metode pembelajaran tertentu yang harus digunakan dalam proses pembelajaran pendidikan nasional. Hanya saja pemerintah memberikan batasan-batasan aturan yang harus dilaksanakan di dalam proses pembelajaran sebagaimana di atas.

Berdasarkan uraian di atas, lembaga pendidikan yang baik dan berhasil adalah lembaga pendidikan yang membuka peluang seluasluasnya bagi para pendidik untuk mengadakan kombinasi variasi penggunaan strategi dan metode pelaksanaan kurikulum sesuai dengan watak pelajaran dan keadaan kondisi siswa yang mengikutinya, sehingga tercapainya tujuan kurikulum atau pendidikan dengan efektif dan efesien. Sebagaimana pendapatnya Soedijarto, apabila terjadi penurunan mutu pendidikan, maka yang pertama kali yang harus diamati dan dianalisis adalah pada kualitas proses belajar mengajar yang terjadi di dalam kelas bukan pada langsung isi kurikulum. ${ }^{1}$ Sebagaimana juga pendapatnya Tho ${ }^{4}$ mas Lickona, metode sangat penting dalam pendidikan nilai, peran guru 
sebagai teladan dan pembimbing, membangun masyarakat yang toleran, harmonis, dan bermoral. Pertemuan-pertemuan di dalam kelas harus mampu menciptakan nilai-nilai saling menghargai dan tanggung jawab dalam kehidupan kelas. ${ }^{1}$

Dengan demikian, strategi dan metode merupakan aspek yang sangat krusial, sama pentingnya dengan materi pelajaran itu sendiri, karena strategi dan metode pelaksanaan kurikulum yang berlangsung di dalam kelas adalah sangat menentukan dalam tingkat keberhasilan tujuan kurikulum atau pendidikan. Nila-nilai pendidikan dan pengajaran akan secara alami mudah tertanam dalam diri siswa apabila disampaikan dengan baik dan menyenangkan, dengan tidak memaksakan kehendak merupakan prilaku alami yang akan mudah diterima dan tertanam dalam diri siswa.

\section{Model Evaluasi Manajemen Kurikulum Pesantren di Jawa Timur}

Evaluasi adalah suatu kegiatan yang dilakukan untuk mengetahui sejauh mana program yang di rencanakan berjalan sesuai yang diinginkan. Kegiatan ini berupa penilaian dan perbaikanperbaikan dari kegiatan yang kurang berjalan sesuai yang diinginkan. ${ }^{1}$

Untuk paparan data di atas, evaluasi kurikulum yang dilakukan oleh pesantren khususnya dikabupaten Jember adalah mengadakan evaluasi rutin yang dilakukan dalam satu bulan sekali atau triwulan yang berfokus pada kegiatan dan kurikulum pondok dan juga Madrasah Diniyah dalam pelaksanaan membentuk karakter santri. Misalnya seperti tes pembacaan kitab, pembacaan manaqib dan rotib al-haddat, dan lain-lain secara langsung yang didampingi oleh ustadz. Hal ini dilakukan agar

1 Thomas Lickona, Education for Charakter, ter ${ }^{5}$ jemahan oleh Juma Abdu Wamaungo, (Jakarta: Bumi Aksara: 2013), 14.

${ }^{1}$ Rounaqun Na'ma, "Manajemen Evaluasi Pen ${ }^{6}$ didikan Pondok Peantren Asrama Pelajar Islam Kesugihan Cilacap”. (Skripsi: Institut Agama Islam Negeri Purwokerto, 2016), 8 
dapat mengetahui sejauh mana santri pondok dalam prosesnya melakukan dengan sungguh-sungguh. Dan juga rapat evaluasi dilakukan di akhir semester yang dilakukan pengecekan kitab kuning, jika ada yang masih bolong dengan catatan diberi ta'ziran/tindakan adalagi hafalan dan lalaran untuk mengasah santri selama mengikuti kegiatan di pesantren ini.

Kegiatan evaluasi kurikulum merupakan keharusan yang esensial dalam rangka pengembangan program pendidikan

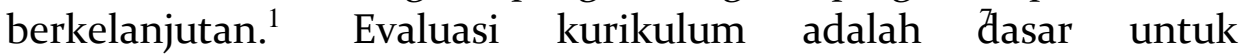
mendapatkan umpan balik pada perbaikan proses belajar mengajar selanjutnya, karena proses belajar mengajar sifatnya berlangsung terus menerus yang selalu memerlukan penyempurnaan untuk tercapainya tujuan pendidikan yang maksimal. Sebagaiman pendapatnya Benjamin S. Bloom evaluasi adalah sebagai kumpulan realitas yang disusun secara sistematis guna memperoleh pengetahuan mengenai terjadi tidaknya perubahan dalam prestasi anak didik. $^{1}$

Perangkat pelaksanaan evaluasi Pesantren di Jawa Timur Khususnya Pesantren yang ada diKabupaten Jember cukup lengkap dan berjalan dengan baik meskipun tidak lepas dari kekurangan. Objek evaluasi di pesantren di Jawa Timur, adalah meliputi: input (masukan), proses, output/outcome, dan dampak. Kemudian pelaksanaan pengawasan tidak hanya dilakukan oleh kepala madrasah selaku administrator dan supervisor, tetapi juga secara berkala dilakukan oleh pengurus Pesantren melalui kepala biro madaris yang langsung membawahi lembaga-lembaga pendidikan yang ada dibawah naungan Pesantren, demikian juga pengawasan secara berkala dilakukan oleh pengurus yayasan Pesantren yang secara formal adalah lembaga yang menaungi lembaga-lembaga pendidikan yang berada di Pesantren Tersebut, dan juga evaluasi dilakukan secara mandiri oleh koordinator bidang, litbang, guru, dan 2009), 145 .

Muhammad Zaini, Pengembangan Kurikul'um (Yogyakarta : Teras,

${ }^{1}$ Hasan Basri dan Beni Ahmad Saebani, Ilmu P $P^{8}$ endidikan Islam (Bandung : CV. Pustaka Setia, 2010), 203. 
stakeholder, sedangkan alat atau media evaluasinya adalah: tes tulis dan praktik, angket, wawancara, pengamatan terus menerus, laporan-laporan atau masukan, kemudian kebijakan evaluasinya melalui: rapat pengurus Pesantren, rapat pengurus yayasan, rapat pimpinan.

Hal ini diperkuat oleh pendapat salah satu pengurus pondok pesantren di jawa timur dalam farum rapat yang melibatkan semua elemen pesantren bahwa "tes lisan, tulis dan praktik digunakan untuk menilai tingkat keberhasilan proses pembelajaran dan menilai tingkat kecakapan santri sebelumnya. sedangkan angket digunakan untuk mengetahui bakat, dan minat santri. Kemudian pengamatan terus menerus dan wawancara digunakan untuk proses pelaksanaan kurikulum seperti strategi dan metode yang digunakan serta proses program-program pendidikan yang lainnya. Selanjutnya laporanlaporan atau masukan biasanya sering digunakan dalam menggali informasi penilaian masyarakat terhadap produk/lulusan pesantren". 1

Sebagaimana pendapatnya Nana Sudjana, objek evaluasi kurikulum adalah meliputi: input, proses, output/outcome, dan dampak. $^{2}$ Sementara itu, pelaku evaluasi, dala ${ }^{0} \mathrm{~m}$ konteks lembaga pendidikan formal, menurut Oemar Hamalik bertingkat sebagaimana berikut: guru bidang studi, kepala sekolah, kandep dan kanwil, administrator tingkat pusat, serta orang tua dan masyarakat. ${ }^{2} \quad$ Paling tidak ada dua indikator keberhasilan pelaksanaan kurikulum di pesantren. Pertama, tercapainya tujuan institusional, tujuan kurikuler, dan tujuan instruksional yang di dalamnya salah satunya adalah mampu membaca dan menjelaskan pelajaran-pelajaran yang bersumber dari kitab kuning. Kedua, terlaksananya dengan baik semua program-program kerja semesteran dan tahunan.

2 Ahmadi, Syukron Nafis, Manajemen Pendidikan Islam, (Yogyakarta: Laksbang Pressindo, 2012), 254

2 Maurice R. Hecht, What Happens in Mahagement: Principles and Practices, (USA: Amocom. 2009), 143 
Hal ini sesuai dengan pendapat Mastuhu. Menurutnya, indikator keberhasilan proses pembelajaran di Pesantren ditentukan oleh penampilan kemampuan santri dalam mengajarkan kitab kuning kepada orang lain. Jika audience-nya merasa puas, maka santri yang bersangkutan telah lulus. ${ }^{2}$ Dengan demikian, kriteria keberhasilan pelaksanaan kurikulum di pesantren adalah diukur dengan berhasil tidaknya santri yang bersangkutan dalam menguasai dan mengajarkan kitab kuning pada orang lain. Kemudian evaluatornya adalah: kiai, asatidz, orang tua, dan masyarakat.

Dalam Undang-undang Nomor 20 Tahun 2003 tentang sistem pendidikan nasional, konsep evaluasi telah diatur pada bab XVI, bagian ke satu, pasal 57, 58, dan 59, yaitu: ${ }^{2}$

1. Evaluasi dilakukan dalam rangka pengendalian mutu pendidikan secara nasional sebagai bentuk akuntabilitas penyelenggara pendidikan kepada pihak-pihak yang berkepentingan.

2. Evaluasi dilakukan terhadap peserta didik, lembaga, dan program pendidikan pada jalur formal dan nonformal untuk semua jenjang, satuan, dan jenis pendidikan.

3. Evaluasi hasil belajar peserta didik dilakukan oleh pendidik untuk memantau proses, kemajuan, dan perbaikan hasil belajar peserta didik secara berkesinambungan.

4. Evaluasi peserta didik, satuan pendidikan, dan program pendidikan dilakukan oleh lembaga mandiri, secara berkala, menyeluruh, transparan, dan sistematik untuk menilai pencapaian standar pendidikan nasional.

5. Pemerintah dan pemerintah daerah melakukan evaluasi terhadap pengelola, satuan, jalur, jenjang, dan jenis pendidikan.

6. Masyarakat dan/atau organisasi profesi dapat membentuk lembaga yang mandiri untuk melakukan evaluasi.

Hal ini sesuai dengan pendapat salah satu pengurus pondok pesantren dijawa timur: dalam menilai berhasil tidaknya tujuan pendidikan atau terlaksana tidaknya program-program pendidikan

2 Alberty Elsie and J. Horald b Alberty, Reor ${ }^{2}$ ganizing the High School Curriculum, (New York: The MacMillan Company. 1962), 156

2 Undang-Undang Nomor 18 tahun 2019 Tentan̉g Pesantren. 
adalah dengan menilai empat komponen, yaitu: (1) masukan, meliputi: jumlah, bakat, dan minat siswa serta kecakapan sebelumnya, bahan pelajaran, alat-alat pembelajaran, media dan sumber belajar, jumlah dan kualitas guru, sistem administrasi, sarana dan prasarana, serta lingkungan masyarakat. (2) proses, meliputi: strategi dan proses pelaksanaan kurikulum, bimbingan penyuluhan, administrasi supervisi, dan penilaian hasil belajar. (3) output atau outcome meliputi: pengetahuan, sikap, dan keterampilan para siswa setelah mengalami proses pendidikan baik berupa penilaian secara kualitatif ataupun kuantitatif. (4) dampak, meliputi: kemandirian, tanggungjawab, kemampuan intelektual, hubungan sosial, akhlaq, dan etos kerja para alumi setelah kembali ke masyarakat.

Adapun instrumen evaluasi kurikulum yang digunakan evaluator dalam mengevaluasi kurikulum beliau juga menjelaskan: evaluator kurikulum di pondok pesantren terdiri dari berbagai unsur, yaitu: (1) pengurus pesantren instrumennya adalah laporan kepala sekolah yang disampaikan pada biro madaris; (2) pengurus yayasan instrumennya adalah laporan dari kepala sekolah; (3) kepala sekolah instrumennya melalui pengamatan langsung, wawancara, laporan dari wakil kepala sekolah, ketua litbang, guru bk, guru mapel dan kelas, alumni dan stakeholder; (4) wakil kepala sekolah instrumennya melalui pengamatan langsung dan angket; (5) litbang pesantren instrumennya melalui pengamatan langsung, angket, wawancara, serta laporan para guru, alumni dan stakeholder; (6) kordinator bidang instrumennya melalui pengamatan langsung; (7) guru bk, guru mapel, dan kelas instrumennya melalui pengamatan langsung dan penilaian; (8) para alumni dan stakeholder melalui pengamatan langsung terhadap produk/lulusan pesantren di lingkungan masyarakat atau perguruan tinggi.

Berdasarkan penjelasan di atas instrumen yang digunakan dalam evaluasi kurikulum, adalah: tes tulis dan praktik, angket, wawancara, pengamatan terus menerus, laporan-laporan atau masukan dari berbagai pihak, khususnya dari alumni dan stakeholder. Kemudian mengenai teknis pelaksanaan penerapan instrument evaluasi pada objek evaluasi, waka kesiswaan mencoba 
mengklasifikasikan tes tulis dan praktik digunakan untuk menilai tingkat keberhasilan proses pembelajaran dan menilai tingkat kecakapan siswa sebelumnya. Sedangkan angket digunakan untuk mengetahui bakat, dan minat siswa. Kemudian pengamatan terus menerus dan wawancara digunakan untuk proses pelaksanaan kurikulum seperti strategi dan metode yang digunakan serta proses program-program pendidikan yang lainnya. Selanjutnya laporanlaporan atau masukan biasanya sering digunakan dalam menggali informasi penilaian masyarakat terhadap produk/lulusan.

Berdasarkan pembahasan di atas, pondok pesantren di Jawa Timur telah menjalankan standar evaluasi kurikulum pesantren dan evaluasi kurikulum standar pendidikan nasional, yakni pemantauan terhadap perkembangan penguasaan keilmuan keislaman yang bersumber dari kitab-kitab kuning dan keilmuan-keilmuan lainnya yang mengacu pada jenis-jenis keilmuan sebagaimana yang telah ditetapkan dalam undang-undang republik indonesia nomor 20 tahun 2003 tentang sistem pendidikan nasional pada bab x pasal 37 dan peraturan pemerintah republik indonesia nomor 19 tahun 2005 tentang standar nasional pendidikan pada bab iii pasal 6 dan 7 .

\section{Simpulan}

Berdasarkan pembahasan di atas, peneliti mengambil kesimpulan: Pertama, penyusunan rencana program kerja disesuaikan dengan visi, misi dan tujuan pondok pesantren yang jelas dan terarah. Kedua, adanya keterlibatan dewan asatidz dan stakeholder dalam mendukung program lembaga. Konsep pelaksanaan manajemen pengembangan kurikulum pesantren bertujuan untuk melaksanakan kurikulum yang telah direncanakan hal ini terlaksananya hasil dari perencanaan kurikulum pesantren tersebut. Adapun kegiatan yang harus dilaksanakan demi terwujudnya tujuan dan visi/misi pesantren untuk membentuk karakter santri antara lain: ( 1 ) Strategi inquiry, meliputi: metode diskusi, tanya jawab, pemberian tugas, bahts al-masail, dan jigsaw. (2) Strategi inquiry sosial, meliputi: metode karya wisata dan percobaan (eksperimen), (3) Strategi exposition learning, meliputi: 
metode wetonan atau bandongan dan ceramah, (4) Strategi rote learning, meliputi: metode hafalah, (5) Strategi contextual teaching learning, meliputi: metode demonstrasi dan praktik. Ketiga, pesantren sering melakukan evaluasi guna mengetahui tingkat keberhasila program yang dilakukan. Evaluasi rutin dilakukan tiap bulan atau triwulan yang berfokus pada kegiatan pesantren.

\section{Referensi}

Ahmadi dan Syukron Nafis. Manajemen Pendidikan Islam, Yogyakarta: Laksbang Pressindo, 2012.

Baharuddin dan Moh. Makin. Manajemen Pendidikan Islam, Malang: UIN-Maliki Malang Press, 2016.

Bambang Ismaya. Pengelolaan pendidikan, Bandung: PT Rafika Aditama, 2015.

Basri, Hasan dan Beni Ahmad Saebani. Ilmu Pendidikan Islam. Bandung: CV. Pustaka Setia, 2010.

Departemen Agama RI. Undang-undang dan Peraturan Pemerintah RI, Jakarta: Direktorat Jenderal Pendidikan Islam Departemen Agama RI, 2006.

Elsie, Alberty and J. Horald b Alberty. Reorganizing the High School Curriculum, New York: The MacMillan Company, 1962.

Idi, Abdullah. Pengembangan Kurikulum Teori \& Praktik, Yogyakarta: Ar-Ruzz Media, 2016.

Kokom, Euis dan Yaya Suryan. "Manajemen Kurikulum Pesantren," Jurnal Islamic Education Manajemen 2 (1) 2017. https://journal.uinsgd.ac.id/index.php/isema/article/view/499 5

Lickona, Thomas. Education for Charakter. terjemahan oleh Juma Abdu Wamaungo. Bumi Aksara, 2013.

Lubis, Amri Yusuf. Pelaksanaan Manajemen Kurikulum pada SMA Negeri 1 Buenggala Kabupaten Aceh Besar: Jurnal Administrasi 
Pendidikan Pascasarjana Universitas Syiah Kuala. Vol.3 No.1 (2015).

Maurice R. Hecht. What Happens in Management: Principles and Practices, USA: Amocom, 2009.

Mulyatiningsih, Endang. Metode Penelitian Terapan Bidang Pendidikan. Bandung: Alfabeta, 2014.

Na'ma, Rounaqun, Manajemen Evaluasi Pendidikan Pondok Peantren Asrama Pelajar Islam Kesugihan Cilacap”. (Skripsi: Institut Agama Islam Negeri Purwokerto, 2016.

Nurul Indana, Leny Nurvita. "Implementasi Manajemne Kurikulum Pesantren.” Al-Idaroh: Jurnal Study Manajemen Pendidikan

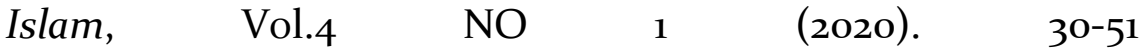
https://jurnal.stituwjombang.ac.id/index.php/alidaroh/article/download/129/87/310

Sodiqin, Hasan dan Diding Nurdin. "Kemampuan Manajerial Kepala Madrasah dan Kinerja Mengajar Guru dalam Mutu Pendidikan.” Jurnal Administrasi Pendidikan.Vol. XXIII No. 2 (2016)

St. Syamsudduha. Manajemen Pesatren (Teori dan Praktek), Yogyakarta: Graha Guru, 2004.

Sunaryo Putro, 2020. Pengembangan KurikulumPondok Pesantren Modern Ad-dhuha. Jurnal: Tarbawi, Vol 17 No 1 https://ejournal.unisnu.ac.id/JPIT/article/download/1109/pdf

Uliatunida, Nida. "Perencanaan kurikulum untuk mencapai tujuan pendidikan." Jurnal Ilmu Pendidikan dan Dakwah, Vol.2 No 1 (2020).

Undang-Undang Republik Indonesia Nomor 20 Tahun 2003 tentang Sistem Pendidikan Nasional.

Zaini, Muhammad. Pengembangan Kurikulum, Yogyakarta: Teras, 2009. 